\title{
MÚSICA POPULAR BRASILEIRA E POESIA: A VALORIZAÇÃO DO “PEQUENO” EM CHICO BUARQUE E MANUEL BANDEIRA.
}

RESUMO:

O objetivo principal deste texto é discutir, através de um estudo comparativo, a valorização do "pequeno" (entendido como: o detalhe, o humilde, e as coisas consideradas simples e banais do cotidiano) e do desqual ificado nas letras musicais de Chico Buarque e na obra poética de Manuel Bandeira.

PALAVRAS-CHAVE: Chico, Bandeira, humildade, detalhe.

0 objetivo principal de nosso trabalho foi constatar, através de um estudo comparativo, a valorização do "pequeno" (entendido como: 0 detalhe, o humilde e as coisas consideradas simples e banais do cotidiano) e do desqualificado nas letras musicais de Chico Buarque e na obra poética de Manuel Bandeira. Ao tratarmos das obras destes dois grandes autores nacionais examinamos, ainda, as relações existentes entre a Música Popular Brasileira - utilizando, especificadamente, as canções de Chico Buarque - e a poesia; já que Chico Buarque, como compositor, utiliza-se de técnicas poéticas para construir suas canções e Manuel Bandeira, enquanto poeta, faz uso de técnicas musicais para, em alguns momentos, construir seus poemas. Além de ser o poeta mais musicado do país, Bandeira teve uma relação frutífera tanto com músicos eruditos quanto músicos populares freqüentadores, como ele, do ambiente boêmio e musical da Lapa, lugar onde se concentravam grandes sambistas e intelectuais nas décadas de 20 e 30.

Durante os dois primeiros séculos de colonização, os tipos de música ouvida no Brasil eram cantos das danças rituais dos indígenas, os batuques africanos |* Mestre em Letras: Estudos Literários (Área de concentração: Teoria da Literatura), 2001. 


\section{EMTESE}

Belo Horizonte, v. 6, p. I-253, ago. 2003

à base de instrumentos de percussão e as cantigas dos colonizadores europeus representados por gêneros musicais do tempo de formação dos primeiros burgos medievais dos séculos XII e XIV, conhecidos como romances, xácaras, lundus e serrarias.

Segundo o historiador José Ramos Tinhorão, o samba e a marcha surgiram e fixaram-se no Brasil num período de sessenta anos, que vai de 1870 até 1930. Até então, no Brasil, o que se ouvia era a música operística, entre a elite; as polcas, shottishes e quadrilhas, gêneros apreciados pelas camadas médias e "populares", e o batuque de origem africana, exclusivo dos negros, que formavam o grosso da camada mais baixa. A música brasileira começou a se formar devido justamente à interferência desses elementos musicais.

Mas foi a partir do estabelecimento da divulgação por meio do disco e do rádio, a partir do final da década de 30, que nasceu uma maneira mais digna de se divulgar o samba. Iniciado por Donga e os seus seguidores, ele ganha espaço com a geração dos compositores ligados às camadas populares do Rio de Janeiro, como, por exemplo: Ismael Silva (fundador da primeira escola de samba), Antônio Marsal, Heitor dos Prazeres. A partir de então, a música popular, em especial o samba, não é mais uma atividade característica da "baixa classe média", surgindo entre seus compositores nomes de importância como Noel Rosa (que chegou a ser estudante de Medicina), Ari Barroso (estudante de Direito), Mário Reis (também estudante de Direito), Orestes Barbosa (que publicou Penumbra Sagrada, livro de versos elogiado por Agripino Grieco), entre outros.

0 compositor de samba, nos anos 20 e 30 , pode ser considerado como um agente mediador entre mundos culturais distintos, como o dos salões intelectuais e o das festas populares das camadas mais pobres da cidade. Essa característica foi apontada por observadores da época, como fica claro neste comentário de Manuel Bandeira sobre o sambista Sinhô: "Ele era o traço mais expressivo ligando os poetas, os artistas, a sociedade fina e culta às camadas profundas da ralé urbana. Daí a fascinação que despertava em toda gente quando levado a um salão" (Bandeira: 63) Esse fascínio, que era confundido com um interesse pelo popular que cada vez mais competia com os interesses eruditos dos salões da elite brasileira (vide a semana da arte moderna e o interesse modernista, em geral, pela cultura popular brasileira), 
temos em Manuel Bandeira, que chega a ver no sambista o símbolo por excelência da cultura carioca: "o que há de mais povo e de carioca tinha em Sinhô a sua personificação mais típica, mais genuína e mais profunda" (Bandeira: 63).

Nessa fase, processa-se a mistura de elementos da qual nascia o samba carioca, em cuja geografia destaca-se a Praça Onze, onde se misturavam a cultura negra e a branca-européia. Assim, o samba não teve uma origem pura, apesar de nascer das mãos e das vozes negras que vinham do bairro da Saúde. À cultura negra incorporavam-se elementos de outras culturas.

De acordo com Hermano Vianna (1995: 151),

A invenção do samba como música nacional foi um processo que envolveu muitos grupos sociais diferentes. 0 samba não se transformou em música nacional através dos esforços de um grupo social ou étnico (o "morro"). Muitos grupos e indivíduos (negros, ciganos, baianos, cariocas, intelectuais, politicos, folcloristas, compositores eruditos, franceses, milionários, poetas (...) participaram, com maior ou menor tenacidade, de sua "fixação" como gênero musical de sua nacionalização.

Este período, marcadamente áureo na música popular brasileira, propiciou o surgimento de compositores, poetas e cantores até hoje famosos em nosso cancioneiro popular, fazendo com que o nosso samba se tornasse matéria prima tipo exportação.

Em 1958 surge a Bossa Nova, estilo musical que rompe com a herança do samba "tradicional", trazendo uma renovação à música popular brasileira. As inovações propostas pela Bossa Nova, além de abrangerem o campo da interpretação, acompanhamento, linguagem instrumental, harmonização e ritmo, forjaram a formação de um novo estilo composicional e incorporaram a todos os recursos musicais conquistados uma temática literária do seu tempo.

De acordo com Júlio Medaglia (1978: 78), a revolução proposta pelo disco e a Bossa Nova, em seu aspecto mais original, seria a de

reduzir e concentrar ao máximo os elementos poéticos e musicais, abandonar todas as práticas musicais demagógicas e metafóricas do tipo "toda quimera se esfuma na brancura da espuma".(...) Uma música voltada para o detalhe, e para a elaboração mais refinada com base numa temática extraída do próprio cotidiano: do humor, das aspirações espirituais, e dos problemas da faixa social onde ela tem origem. É a música que todos podem cantar, pois nega a participação do "cantor-solista-virtuosi" (...). 


\section{EMTESE}

Belo Horizonte, v. 6, p. I-253, ago. 2003

Historicamente a MPB surge a partir do desenvolvimento da Bossa Nova, na década de 60; na opinião de Walnice Nogueira Galvão (1976: 93), a MPB tinha o projeto de "dizer a verdade" sobre a realidade imediata. Para Walnice (1976: 93), a nova proposta da "Moderna Música Popular Brasileira" reside no compromisso com uma realidade cotidiana e presente, com o "aqui agora". "Esse compromisso leva-a a adotar a desmistificação militante, derrubando velhos mitos que se encarnavam em lugares comuns da canção popular, como a louvação da beleza do morro e do sertão, da vida simples mas plena do favelado e do sertanejo".

A canção popular da década de 60 e 70 tem um caráter circunstancial, assumindo muitas vezes uma dimensão quase jornalística, passando a refletir diretamente os acontecimentos do dia a dia. A canção popular torna-se veículo de comunicação que diz o que os canais competentes não podiam dizer.

0 que notamos é que os compositores da nossa música popular passam a marcar uma nova expectativa em relação à letra da canção popular. Como nos diz Heloísa Buarque (1980: 54), "a letra passa a exigir um certo status literário, um estatuto de qualidade que se contrapõe à inexpressividade da poesia do momento". Os jovens compositores, de formação universitária, irão lançar mão de artifícios poéticos na construção de suas letras, através do fragmentado, da intertextualidade e da própria referência à tradição literária brasileira. Nesse sentido, a dimensão poética da música popular deixa de estar no uso do lirismo, ou de se fazer segundo os padrões da poesia popular, para assumir uma dicção culta.

É a partir de toda essa tradição do samba e da década de sessenta e seus acontecimentos políticos e culturais, que Chico Buarque vai surgir no cenário cultural brasileiro. Ele surge com suas canções extremamente elaboradas musical e poeticamente, construídas a partir de uma tradição do samba de Noel Rosa, Cartola, Pixinguinha, Ismael Silva, entre outros, e da musicalidade e do canto renovador da Bossa Nova, continuando a tradição de Tom Jobim e João Gilberto. Como bem o definiu Caetano Veloso ao dizer que "Chico Buarque anda pra frente carregando toda uma tradição".

Chico se vincula a uma vertente do samba mais tradicional, inserindo neste um trabalho poético minucioso, com composições extremamente bem elaboradas 
poética e musicalmente. Ele se relaciona com a tradição literária brasileira, mantendo um diálogo frutífero com a literatura, seja com a utilização de recursos estilísticos comumente pertencentes ao discurso poético para construir suas canções, como também na sua criação teatral ou como romancista. Nesse diálogo que Chico mantém até hoje com a literatura podemos notar o extremo cuidado, o apuro técnico, o trabalho poético minucioso que o compositor desenvolve para elaborar suas composições.

Em grande parte da história, a poesia e a música sempre foram expressões artísticas que se utilizaram de técnicas semelhantes para se realizarem formalmente. No entanto, o processo da criação musical é bem diferente do da poesia impressa; a canção popular é necessariamente música e letra, construídas de forma que suas partes constituintes se tornem uma só. A poesia, mesmo utilizando o ritmo e a musicalidade para se construir, é feita de maneira independente da música, no seu sentido sonoro, produzido por instrumentos musicais. Assim, a poesia emprega de elementos da música, como a música usa elementos da poesia. Todavia, são produções culturais distintas, uma não é melhor do que a outra: são apenas diferentes. Chico nunca quis ser considerado poeta e nem gosta que suas letras musicais sejam lidas como poemas.

0 início da produção poética de Manuel Bandeira foi influenciado pela tradição parnasiano-simbolista, que usava da linguagem de estilo elevado e das metáforas penumbristas para se expressar. Logo após A cinza das Horas, já percebemos, no poeta, um processo de libertação de sua herança parnasiano-simbolista; sua linguagem se liberta do estilo elevado forjando um estilo humilde através da vinculação em sua poética de elementos comumente ignorados pela tradição parnasiana: a linguagem coloquial, elementos folclóricos, o verso livre como bem demonstram os seus poemas: "Poética", "Evocação do Recife", entre outros.

0 poeta também manterá um diālogo frutīfero com a música, arte que cultivou em toda a sua vida, utilizando-a, em alguns momentos, para construir alguns de seus poemas, e que também o ajudou a se relacionar com a cultura popular, como podemos notar em poemas como "Debussy", "Temas e voltas", "Cantiga", "Berimbau", entre outros. Bandeira, apesar de se autodenominar poeta menor, se revela um dos poetas maiores de nossa língua. 


\section{EMTESE}

Belo Horizonte, v. 6, p. I-253, ago. 2003

A relação de aproximação que tanto Chico quanto Bandeira têm com a cultura popular e seu povo, entre a música e a poesia, e o extremo cuidado que ambos têm para a criação de suas produções artísticas, confluirão em algumas temáticas presentes em suas obras, principalmente expressas pelo carnaval, pelos desvalidos e pela infância.

0 carnaval, festa popular que tanto Chico quanto Bandeira vão contemplar, aparece através dos elementos libertadores desse rito dionisíaco da libertação sexual ou poética: nas referências à máscara e à fantasia, podemos notar a inversão de papéis sociais, proporcionada pela festa popular; na utilização da carnavalização do texto literário, observa-se a libertação das estruturas tradicionais do bom poetar, através da paródia, da intertextualidade e da inserção de novas temáticas nos textos poéticos.

A presença dos desvalidos nas obras de nossos autores é tão evidente que chegam até mesmo, em algumas canções ou poemas, a estar presentes vários destes tipos. No entanto, a valorização do desqualificado, pelos autores, não diz respeito somente à presença dos desvalidos em suas poéticas, tornando-se uma atitude estética que vai se refletir em suas poéticas através da linguagem popular, da retirada da poesia do cotidiano, enfim, de onde menos se espera.

Finalmente, através do tema da infância, a criança e seu mundo propício à imaginação e ao sonho, são vistos pelos autores como um lugar utópico, onde se encontra a felicidade, e também como fonte de inspiração poética, já que a imaginação é um elemento essencial para a criação artística. Chico e Bandeira também vão refletir em suas poéticas sobre a situação da criança desprotegida sujeita aos desenganos da vida, seja através do menino abandonado em "Pivete", seja através das crianças raquíticas e trabalhadoras em "Meninos carvoeiros".

Como bem definem Antonio Candido e Gilda de Mello e Souza, em sua introdução a Estrela da Vida Inteira, a poesia de Bandeira pode ser pensada de vários modos; um deles seria pensá-la com referência aos dois pólos da Arte, isto é, "o que adere estritamente ao real e o que procura subvertê-10 por meio de uma deformação voluntária. Ambos são legítimos, e tanto num quanto noutro Manuel Bandeira denota maestria que faz aceitá-los como expressões válidas da sua personalidade 
literária." (1986: IX) A partir desta consideração, podemos notar que tanto o lírico quanto o social estão presentes na poética de Manuel Bandeira. Os críticos continuam nos dizendo que

a mão que traça o caminho dos pequenos carvoeiros na poeira da tarde, ou registra a mudança do pobre Misael pelos bairros do Rio, é a mesma que descreve as piruetas do cavalo branco de Mozart entrando no céu, ou evapora as carnes das mulheres em flores e estrelas de um ambiente mágico ou saturado das paixões da terra." (1986: IX)

Pode-se dizer o mesmo das composições de Chico Buarque, que vão apresentar uma relação semelhante entre o social e o lírico, como, por exemplo, "Pedro pedreiro" e "Construção" (canções com forte caráter social) ou "A banda" e "Ela desatinou", (canções preponderantemente líricas). A diferença entre os dois autores é que Bandeira é geralmente visto como poeta lírico, enquanto Chico Buarque aparece como compositor engajado. Nesse sentido, a relação entre Bandeira e Chico, de forma paradoxal, se entrelaça e se combina perfeitamente.

Concluiu-se, portanto, que a valorização do "pequeno", com todas as especificidades que apresentam as obras de Chico Buarque e Manuel Bandeira, pode ser vista antes de tudo como uma postura estética, conquanto apresente inevitavelmente um aspecto social.

ABSTRACT :

This essay aims at a comparative analysis of Chico Buarque's lyrics and Manuel Bandeira's poems, focusing on their concern with "the small" as a category including humility, the love of detail and the representation of simple and trivial everyday things.

KEY WORDS: Chico, Bandeira, humility, detail. 


\section{EM TESE}

Belo Horizonte, v. 6, p. I-253, ago. 2003

REFERÊNCIAS BIBLIOGRÁFICAS

BANDEIRA, Manuel. Manuel Bandeira: Seleta de prosa. Júlio Castañon Guimarães (Org:) Rio de Janeiro: José 01 ympio, [s.d.].

CANDIDO, Antonio; MELO E SOUZA, Gilda. Introdução à Estrela da Vida Inteira. Bandeira, Manuel. Estrela da Vida Inteira: poesias reunidas e poemas traduzidos. Rio de Janeiro: José 01ympio, 1991.

GALVÃo, Walnice Nogueira. Uma análise ideológica da MPB. Saco de gatos: ensaios críticos. São Paulo: Duas Cidades, 1976.

HOLLANDA, Heloísa Buarque de. Impressões de viagem. São Paulo: Brasiliense, 1980.

MEdAgLiA, Júlio. Balanço da Bossa Nova. Campos, Augusto de. Balanço da bossa e outras bossas. 2. ed. São Paulo: Perspectiva, 1974.

TINHORÃo, José Ramos. Pequena história da música popular. São Paulo: Círculo do Livro, [s.d.].

VIANNA, Hermano. O mistério do samba. Rio de Janeiro: Jorge Zahar; UFRJ, 1995. 